\title{
The European Council and the European Union's external activities. Forming relations with eastern neighbors ${ }^{1}$
}

\begin{abstract}
The modification process of the European Union's institutional order appears to be permanent. One of the elements of this tendency is the position of the European Council, which is especially interesting in the field of stimulating external EU activities. The aim of this analysis is to explore the EC's engagement in initiating foreign relations, taking the eastern neighborhood as an example. The paper reviews the European Council's meetings in the period of 2008-2016, concluding that the EC actively responded to external challenges and created a political impetus for the actions of other institutions. The internal debate initiated by the member states from Central and Eastern Europe resulted in the formulation of the Eastern Partnership initiative that the European Council approved and adopted, giving it a political impetus within the European Union. This caused a specific reaction in the neighborhood. The process of association of some eastern partners was accompanied by the need to deal with the challenging response from Russia, which resorted, among other things, to military measures. The European Council's involvement in external actions in the East became a self-deepening process with a changing profile and priorities.
\end{abstract}

Key words: European Council, external activities, Eastern Partnership, European Union

\section{Introduction}

$\mathbf{T}$ he external relations of the European Union are one of the most dynamic areas of the European integration process. On the one hand, the expanding European Union engages in the relations with its new neighbors and the challenges posed in this area, which is particularly notable after the 2004 enlargement. On the other hand, the process of enhanced integration results in the coordination and communitarization of new policies, whereas the institutional structure and EU governance are being transformed. Therefore, recent integration experiences have resulted in foreign policy becoming yet another field of experimentation. Additionally, this is happening against the backdrop of fundamental changes in the international arena, where the stability in the surroundings of Europe is clearly deteriorating. This results in attempts to reinstate the stability in the nearest neighboring countries by means of external measures on the one hand, and the need for the European Union to address its failures in the implementation of these measures on the other.

${ }^{1}$ The article was written as part of a project sponsored by the National Science Centre, Poland (Narodowe Centrum Nauki, NCN): "The European Council in the process of forming formal and informal competences in the realm of the European Union's external activities", no. 2015/19/B/HS5/00131. / Artykuł został przygotowany w ramach projektu finansowanego przez Narodowe Centrum Nauki: „Rada Europejska w procesie kształtowania kompetencji formalnych i nieformalnych w zakresie działań zewnętrznych Unii Europejskiej”, nr 2015/19/B/HS5/00131. 
This analysis aims to show the involvement of the European Council in initiating the external activities of the European Union on the example of relations with its eastern neighbors. In terms of methodology, this study is based on an analysis of the Conclusions of EC meetings in the period 2008-2016. The premise of these considerations is the claim that the European Council is becoming increasingly influential and that, given external challenges, it is taking advantage of its competences to initiate activities and respond to the problems of external policies.

\section{The European Council and external actions of the European Union}

The reform processes within the European Union which were manifested over the last decade, by designing and adopting the Lisbon Treaty, have resulted in a change in the power relations within the framework of the EU's institutional order. This is demonstrated, among other things, by specific EU institutions retaining and/or acquiring formal competences. On the other hand, in the course of their practical operations, they also obtain numerous informal competences, which either reinforce or undermine formal ones.

The European Council is viewed as an institution which has strengthened its position in the legislative and political order introduced by the Lisbon Treaty, and actually continues to grow stronger (Rittelmeyer, 2014, p. 25). It is frequently named the final arbiter and agenda-setter, thereby becoming the genuine "government" of the European Union (Alexandrova, Carammia, Timmermans, 2014, pp. 53, 809, 822). The decisions are made by the European Council in the form of Conclusions which provide "guidance for the EU's institutions" (Werts, 2008, p. 62). The growing importance of the EC is particularly visible in the area of initiating external activities where the $\mathrm{EC}$ has been assigned the role of the leader in responding to international challenges (PrzybylskaMaszner, Rewizorski, 2012, p. 165). According to the Treaty of Lisbon, "the member states consult one another within the European Council 'on any matter of foreign and security policy of general interest in order to determine a common approach" (Werts, 2008, p. 122). There are at least two reasons for these processes.

Firstly, state power plays a dominant role in the intergovernmental logic of the European Council's operations and of international policy. On the one hand, the principle of unanimity means that all member states are equal. On the other hand, the largest states have greater influence on the final decisions, which is especially noticeable in an EU composed of as many as twenty-eight members. More often than not, informal negotiations are held right before the summits (Tallberg, 2008, p. 703), but smaller member states have an opportunity to clearly make their point, nevertheless (Wessels, 2016, p. 145).

Secondly, in the face of serious challenges, the European Council plays the role of an active player capable of rapidly and efficiently responding to actual problems, unlike other institutions which are viewed as less dynamic and more bureaucratic (Rewizorski, 2013 , p. 40). This is particularly important in foreign politics, an area that has been growing more unstable over the last decade (Milczarek, Zajączkowski, 2015, p. 9) and dealing with situations that are deadlocked as a result of divisions between other institutions (Werts, 2008, p. 191). 
The research conducted by Wolfgang Wessels leads to the conclusion that "the record of activities in the area of external action indicates a considerable effort by the European Council to shape a visible profile in the international system. Its performance shows a high frequency and intensity of activities. However the substantial outputs of declarations by the European Council should not conceal the fact that this institution of national leaders has quite often remained divided on many items of common concern" (Wessels, 2016, pp. 223-224).

\section{The European Council and external actions in the East}

In the investigated period, the external relations of the European Union have been determined by at least two factors in the eastern neighborhood: the debate on further enlargement to the East, and Russia reconstituting its imperial position in Eurasia.

Together with the 2004 enlargement to the East, the European Union obtained a new eastern flank and was challenged with the necessity of organizing its relations with its new neighbors, especially Belarus, Ukraine, Moldova and Russia. Western leaders considered this enlargement as exhausting the absorption capacities and - contrary to the Central and Eastern European members - were hesitant towards further enlargements. On the other hand, however, the formation of external relations required the European Union's involvement in order to stabilize the surroundings and to create a more stable international environment around the Union. This resulted in the Eastern Partnership initiative in 2008 that was to bind the post-Soviet neighbors to the European project (Piskorska, 2009).

Those developments were confronted with the reconstruction of the imperial position of Russia in the post-Soviet space. Vladimir Putin's Russia, with the growing military capabilities (fueled by gas and oil revenues), was able to materialize its territorial and political ambitions. This was visible, on the one hand, in the (re)integration project including the Eurasian Economic Union launched in 2014, and on the other, in contesting pro-western tendencies in the post-Soviet space, which cumulated in the Georgian war in 2008 (Nichol, 2009) and the Ukrainian conflict in 2014 (Latosińska, 2016).

To interpret the external involvement of the European Council in the East in the context of the above-presented contextual developments an empirical investigation was undertaken. It follows the conceptual considerations discussed and is based on the analysis of legal documents. The European Council's involvement in the formation of the European Union's external activities in the East was examined on the basis of the Conclusions issued after each EC summit. The period from 2008 to 2016 was investigated. The former date marks the establishment of the Eastern Partnership; the latter brings the investigation to the latest possible moment.

The European Council typically meets four times a year; sometimes, however, additional summits are organized, especially when the European Union is significantly challenged by issues that require immediate reaction. In the following study all the meetings were analyzed and discussed. The table summarizing the findings (Figure 1.) arranges the summits in terms of the numbers of meetings per quarter. It marks not every summit but each quarter of a year (when sometimes one and sometimes more meetings were organized), which consequently allows methodologically comparable time units to be set. 
This enables examining the temporal dynamism of the European Council's involvement in the external policies in the East.

Figure 1. European Council summits' Conclusions with reference to the Eastern Partnership and specific states in the eastern neighborhood

\begin{tabular}{|c|c|c|c|c|c|c|c|c|c|c|}
\hline Year & $\overline{\mathbf{Q}}$ & $\overline{\mathbf{E P}}$ & $\overline{\overline{\mathbf{U}}}$ & $\overline{\mathbf{G}}$ & $\overline{\mathrm{M}}$ & $\overline{\mathbf{B}}$ & $\overline{\mathrm{Ar}}$ & 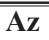 & 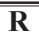 & International context \\
\hline \multirow[t]{4}{*}{2008} & I & & & & & & & & & \\
\hline & II & $\mathrm{x}$ & & & & & & & & Medvedev Presidency \\
\hline & III & $\mathrm{x}$ & $\mathrm{x}$ & $\mathrm{x}$ & & & & & $\mathrm{x}$ & Russian-Georgian war \\
\hline & IV & & & & & & & & & \\
\hline \multirow[t]{4}{*}{2009} & I & $\mathrm{x}$ & $\mathrm{x}$ & $\mathrm{x}$ & $\mathrm{x}$ & $\mathrm{x}$ & $\mathrm{x}$ & $\mathrm{x}$ & & \\
\hline & II & $\mathrm{x}$ & & & & & & & & 1st EP Summit, Prague \\
\hline & III & & & & & & & & & \\
\hline & IV & $\mathrm{x}$ & & & & & & & & \\
\hline \multirow[t]{4}{*}{2010} & $\mathrm{I}$ & & & & & & & & & Customs Union of B., Kazakhstan, and R. \\
\hline & II & & & & & & & & & \\
\hline & III & & $\mathrm{x}$ & & & & & & $\mathrm{x}$ & \\
\hline & IV & & & & & & & & & \\
\hline \multirow[t]{4}{*}{2011} & I & $\mathrm{x}$ & & & & $\mathrm{x}$ & & & & \\
\hline & II & & & & & & & & & \\
\hline & III & & & & & & & & & 2nd EP Summit, Warsaw \\
\hline & IV & $\mathrm{x}$ & & & & & & & & Eurasian Economic Union \\
\hline \multirow[t]{4}{*}{2012} & I & $\mathrm{x}$ & & & & $\mathrm{x}$ & & & & \\
\hline & II & & & & & & & & & Putin Presidency \\
\hline & III & & & & & & & & & \\
\hline & IV & & & & & & & & & \\
\hline \multirow[t]{4}{*}{2013} & I & & & & & & & & & \\
\hline & II & & & & & & & & & \\
\hline & III & $\mathrm{x}$ & & & & & & & & \\
\hline & IV & $\mathrm{x}$ & $\mathrm{x}$ & $\mathrm{x}$ & $\mathrm{x}$ & & & & & 3rd EP Summit, Vilnius; Euromaidan \\
\hline \multirow[t]{4}{*}{2014} & $\mathrm{I}$ & & $\mathrm{x}$ & $\mathrm{x}$ & $\mathrm{x}$ & & & & $\mathrm{x}$ & Euromaidan; Secession of Crimea \\
\hline & II & & $\mathrm{x}$ & $\mathrm{x}$ & $\mathrm{x}$ & & & & $\mathrm{x}$ & Eurasian Economic Union; Secession of Donbas \\
\hline & III & & $\mathrm{x}$ & & & & & & $\mathrm{x}$ & \\
\hline & IV & & $\mathrm{x}$ & & $\mathrm{x}$ & & & & $\mathrm{x}$ & \\
\hline \multirow[t]{4}{*}{2015} & I & & $\mathrm{x}$ & $\mathrm{x}$ & $\mathrm{x}$ & & & & $\mathrm{x}$ & \\
\hline & II & & & & & & & & & 4th EP Summit, Riga \\
\hline & III & & & & & & & & & \\
\hline & IV & & & & & & & & & \\
\hline \multirow[t]{4}{*}{2016} & I & & $\mathrm{x}$ & & & & & & & \\
\hline & II & & & & & & & & & \\
\hline & III & & & & & & & & $\mathrm{x}$ & \\
\hline & IV & & $\mathrm{x}$ & $\mathrm{x}$ & & & & & & \\
\hline
\end{tabular}

EP - Eastern Partnership, U - Ukraine, G - Georgia, M - Moldova, B - Belarus, Ar - Armenia, Az - Azerbaijan, R - Russia.

Source: Author's work based on the Conclusions of the European Council.

Another issue was related to the method of examining the European Council's interest in the eastern neighborhood. It was decided that every reference to the region present in the Conclusions, including both short hints and longer debates, should be noted. These references were subsequently categorized with respect to three indicators: the focus on 
the Eastern Partnership, the focus on specific states of the Eastern Partnership (Ukraine, Georgia, Moldova, Belarus, Armenia and Azerbaijan respectively) and the focus on Russia. This categorization, however, is functional and does not reflect any form of interregionalism (Doidge, 2011, p. 2). The following sections present the three focal points.

\section{The Eastern Partnership}

The Eastern Partnership appears one or two times per year on average in the Conclusions. However, the attention paid to this initiative seems to have climaxed in 2008 and 2009 when it was initiated and implemented. In June 2008, "the European Council welcome[d] the proposals for developing the eastern dimension of the European Neighbourhood Policy, which aim[ed] at enhancing EU policy towards eastern ENP partners in bilateral and multilateral formats" to "promote regional cooperation among the EU's eastern neighbors and between the EU and the region, as well as bilateral cooperation between the EU and each of these countries respectively" (EC 2008a). In September, in the context of the Georgian-Russian war, the European Council stated that "the European Union considers that it is more necessary than ever to support regional cooperation and step up its relations with its eastern neighbours, in particular through its neighbourhood policy $[\ldots]$ and an 'Eastern Partnership' which the European Council wishe[d] to adopt in March 2009" (EC 2008b).

Three summits referred to the Eastern Partnership in 2009. In March, the European Council dedicated a significant part of the Conclusions to the issue declaring that "promoting stability, good governance and economic development in its Eastern neighbourhood is of strategic importance for the European Union" and therefore the "European Council welcomes the establishment of an ambitious Eastern Partnership" as well as "calls for all necessary preparations to be made for the Eastern Partnership launching summit with the partner countries on 7 May 2009." Additionally, the EC called "on the Commission as well as the current and incoming Presidencies to advance speedily with the practical implementation of the Partnership together with the partners" (EC 2009a). In June, a similar enthusiasm was noticeable at the time of launching the Eastern Partnership. The EC again called "upon the Commission and incoming Presidencies to continue their work in line with the Joint Declaration of the Prague Summit of 7 May 2009" (EC 2009b). In December, it welcomed the implementation of the Eastern Partnership (EC 2009c).

For over twenty months that followed, the European Commission did not refer to the Eastern Partnership. It eventually did so in October 2011 (the February Conclusions only frame the policy towards Belarus within the context of the Eastern Partnership (EC 2011a)). The European Council welcomed "the second Eastern Partnership Summit held in Warsaw [and] the intention of the High Representative and the European Commission to propose a roadmap that would list the objectives, instruments and actions with a view to the next Eastern Partnership Summit in the second half of 2013." At the same time, it noted that various states had made various progress in political reforms and declared that "the pace and depth of these countries' political association and economic integration with the EU will depend on their upholding of the democratic principles and rule of law which are the basis of the Partnership" (EC 2011b). In March 2012, this approach 
was confirmed (EC 2012). In October 2013, the European Council looked "forward to the Eastern Partnership Summit in Vilnius on 28 and 29 November 2013," expecting to sign first Association Agreements (EC 2013a) and in December, after the summit, reconfirmed "the European Union's readiness to sign these agreements as soon as possible and no later than the end of August 2014" (EC 2013b).

The Ukrainian crisis eliminated the Eastern Partnership from the documents in favor of Ukraine and Russia themselves as the main focus in the East. The Eastern Partnership did not appear in 2015 and 2016.

The presented overview demonstrates that the initial interest of the European Council in the Eastern Partnership, on the one hand, was associated with the extension of the stability and prosperity zone behind the eastern border of the European Union, and on the other hand, it created a set of clear incentives for the other EU institutions that were to implement the ideas. Together with the first culmination of the process during the Vilnius Summit, the $\mathrm{EC}$ lost interest in the initiative as other external challenges became more relevant.

\section{States of the Eastern Partnership}

The above-presented dynamism of the European Council's interest in the Eastern Partnership is not reflected in its interests in specific states of the Eastern Partnership. All of them were enumerated together only once in the Conclusions, in March 2009, in the context of establishing the Eastern Partnership and with the aim of "accelerating reforms, legislative approximation and further economic integration" (EC 2009a). This is actually the only time in the analyzed period where Armenia and Azerbaijan are mentioned in the Conclusions.

Belarus is mentioned two more times. In the February 2011 Conclusions the European Council "endorsed the conclusions on Belarus adopted by the Foreign Affairs Council on 31 January, including the decision to impose restrictive measures," asking it to "regularly re-examine the situation in Belarus and stand ready to consider further targeted measures in all areas as appropriate" (EC 2011a). In a March meeting next year, the EC introduced a travel ban and froze the assets of the Belarusian regime officials and, additionally, invited "the Council to proceed with its work on further measures. It reiterate[d] the Union's commitment to strengthening its engagement with Belarusian civil society and to supporting the democratic aspirations of the Belarusian people" (EC 2012). Belarus is therefore mentioned with regard to anti-democratic developments which cause negative reactions of EU member states.

From 2013 to 2015, Moldova usually appears in the Conclusions alongside Georgia in the context of association with the European Union. In October 2013, the European Council confirmed "the European Union's readiness to initial similar agreements with the Republic of Moldova and Georgia at the Vilnius Summit, with the aim of signing them by Autumn 2014" (EC 2013a), and in December it welcomed "the initialling by Georgia and the Republic of Moldova of the Association Agreements, including Deep and Comprehensive Free Trade Areas, at the Eastern Partnership Summit in Vilnius on 28-29 November" (EC 2013a). The March 2014 Conclusions confirmed this approach (EC 2014a).Next, the EC "welcomed the signature of the Association Agreements, including Deep and Compre- 
hensive Free Trade Areas" in June (EC 2014b). In October 2014, the Conclusions stressed the role of fair elections in Moldova, referring to the political situation in this state (EC 2014e) and, in March 2015, the hope for quick ratification of the Agreements with both states and Ukraine by all the member states was expressed (EC 2015).

Georgia is mentioned in the Conclusions two times more. First, during the September 2008 meeting, in the context of the war with Russia, where the EC appoints, among others, "a European Union Special Representative for the crisis in Georgia and asks the Council to make the necessary arrangements" (EC 2008b). Second, a reference is made to Georgia in the December 2016 Conclusions in the context of the lifting of visa requirements (which applied also to Ukraine (EC 2016c).

Finally, there is Ukraine, an individual eastern neighbor of the EU which is mentioned most frequently in the European Council's Conclusions in the investigated period. The September 2008 Conclusions stressed "the importance of the forthcoming summit between the European Union and Ukraine" (EC 2008b) and expected progress in negotiation in September 2010 (EC 2010). Later on, the document expressed the "willingness to sign the Association Agreement, including the Deep and Comprehensive Free Trade Area, with Ukraine at the Vilnius Summit" in October 2013 (EC 2013a), and readiness to sign it in December (EC 2013b). Starting with the March 2014 meeting and the developing governmental crisis in Ukraine, and further conflict with Russia, most of the attention was paid to these issues in the following Conclusions. On the one hand, the Conclusions stress that "the European Union supports the Ukrainian people and their right to choose their own future. The European Union stands by the Ukrainian government in its efforts to stabilise Ukraine and undertake reforms. In this context the European Union will pursue further efforts with the international community to assist Ukraine." On the other hand, further steps towards association are stressed (EC 2014a). In June 2014, the support for President Poroshenko was expressed, including its financial form (EC 2014b). In July, the support for a peaceful settlement of the crises was emphasized, alongside "the importance of Ukraine ratifying the Association Agreement with a view to its early provisional application" (EC 2014c). The December Conclusions (EC 2014f) and March 2015 Conclusions (EC 2015) made similar declarations.

Summarizing this section, the six states of the Eastern Partnership form three categories in the Conclusions of the European Council: (1) some are marginally present in the Conclusions due to the lack of either positive or negative developments (Armenia and Azerbaijan); (2) some are a matter of concern due to their domestic problems (Belarus); and (3) some are an object of intensive tightening of the relations (Georgia, Moldova and Ukraine), but in the case of Ukraine after 2014 attention is paid to overcoming the problems with domestic instability and Russian intervention.

\section{Russia}

Russia is the last actor in the eastern neighborhood that is significantly present as a subject of debates of the European Council. It is typically mentioned in the context of problems with Russian aggression against its neighbors while being involved in cooperation with the European Union. 
During the September 2008 meeting of the European Council, it stressed its concerns caused "by the open conflict which has broken out in Georgia, by the resulting violence and by the disproportionate reaction of Russia," condemning its "unilateral decision to recognise the independence of Abkhazia and South Ossetia" and asking for "substantial withdrawal of Russian military forces" form Georgia (EC 2008b).

The September 2010 Conclusions stressed the planned "summit with Russia [that would] provide an opportunity to enhance cooperation with Russia and to discuss in particular its modernization agenda" (EC 2010). Russia appears in the Conclusions again in the context of the Ukrainian crisis in 2014. The March meeting stressed that "the European Union remains committed to uphold the sovereignty and territorial integrity of Ukraine. The European Council does not recognise the illegal referendum in Crimea, which is in clear violation of the Ukrainian Constitution. It strongly condemns the illegal annexation of Crimea and Sevastopol to the Russian Federation and will not recognise it," canceling the next EU-Russia Summit and other bilateral regular summits of the member states (EC 2014a). June Conclusions urged "the Russian Federation to actively use its influence over the illegally armed groups and to stop the flow of weapons and militants across the border, in order to achieve rapid and tangible results in de-escalation" and welcomed "the work undertaken by the Commission to give effect to this policy and the decision to prohibit the import of goods from Crimea and Sevastopol which do not have a Ukrainian certificate" (EC 2014b). In July, the European Council agreed, among others, to "expand the restrictive measures, with a view to targeting entities, including from the Russian Federation, that are materially or financially supporting actions undermining or threatening Ukraine's sovereignty, territorial integrity and independence" (EC 2014c). In October, Russia was called to "respect Ukraine's national sovereignty and territorial integrity and to contribute to the political stabilisation and economic recovery of Ukraine. The European Council reiterates that it will not recognize the illegal annexation of Crimea. The Russian Federation should assume its responsibilities for the full implementation of the Minsk agreements. In particular, Russian authorities should prevent any movement of military, weapons or fighters from its territory into Ukraine" (EC 2014e). At a December meeting, Russia was again asked to "actively engage in and implement fully the Minsk agreements" (EC 2014f). In March 2015, restrictive measures against Russia were again "clearly linked to the complete implementation of the Minsk agreements" (EC 2015) and in October 2016, a strategic policy debate on relations with Russia was held (EC 2016b).

\section{Conclusions}

The above-presented considerations show the deep involvement of the European Council in response to the most urgent issues in the field of external policies. The case of the eastern neighborhood is an emphatic illustration of this process. The internal debate initiated by the member states from Central and Eastern Europe resulted in the formulation of the Eastern Partnership initiative that the European Council approved and adopted, giving it a political impetus within the European Union. This caused a specific reaction in the neighborhood. While some of the partners became involved in the process, 
others remained indifferent. The counter-action of Russia shifted the priorities from the Eastern Partnership as a whole to relations with individual Eastern Partnership members, and with Russia. The process of association of some of the partners was accompanied by the need to deal with the challenging response from Russia, which resorted to military measures. The European Council's involvement in external actions in the East became a self-deepening process with a changing profile and priorities.

\section{Bibliography}

Alexandrova P., Carammia M., Timmermans A. (2014), EU high politics: the policy agenda of the European Council, 1975-2011, in: The European Council and European Governance. The commanding heights of the EU, eds. F. Foret, Y-S. Rittelmeyer, London-New York.

Doidge M. (2011), The European union and Interregionalism. Patterns of Engagement, FurnhamBurlington.

EC 2008a, European Council 19/20 JUNE 2008 Brussels, 17 July 2008, 11018/1/08, REV 1, CONCL 2.

EC 2008b, European Council 1 SEPTEMBER Brussels, 6 October 2008 (07.10), (OR. fr), 12594/2/08, REV 2, CONCL 3.

EC 2009a, European Council 19/20 MARCH Brussels, 20 March 2009, 7880/09, CONCL 1.

EC 2009b, European Council 18/19 JUNE Brussels, 10 July 2009, 11225/2/09, REV 2, CONCL 2.

EC 2009c, European Council 11/13 DECEMBER Brussels, 5 February 2010, EUCO 6/1/09, REV 1, COEUR 6, CONCL 4.

EC 2010, European Council 16 SEPTEMBER Brussels, 12 October 2010, EUCO 21/1/10, REV 1, CO EUR 16, CONCL 3.

EC 2011a, European Council 4 FEBRUARY Brussels, 8 March 2011, EUCO 2/1/11, REV 1, CO EUR 2, CONCL 1.

EC 2011b, European Council 23 OCTOBER Brussels, 23 October 2011, EUCO 52/11, CO EUR 17, CONCL 5.

EC 2012, European Council 1/2 MARCH Brussels, 28 March 2012, EUCO 4/1/12, REV 1, CO EUR 2, CONCL 1.

EC 2013a, European Council 24/25 OCTOBER 2013 Brussels, 25 October 2013, EUCO 169/13, CO EUR 13, CONCL 7.

EC 2013b, European Council 19/20 DECEMBER 2013 Conclusions, Brussels, 20 December 2013, EUCO 217/13, CO EUR 15, CONCL 8.

EC 2014a, European Council 20/21 March 2014 Conclusions, Brussels, 21 March 2014, EUCO 7/14, CO EUR 2, CONCL 1.

EC 2014b, European Council 26/27 JUNE 2014 Conclusions, Brussels, 27 June 2014, EUCO 79/14, CO EUR 4, CONCL 2.

EC 2014c, European Council 16 JULY 2014 Conclusions, Brussels, 16 July 2014, (OR. en), EUCO 147/14, CO EUR 9, CONCL 3.

EC 2014d, European Council 30 AUGUST 2014 Conclusions, Brussels, 30 August 2014, (OR. en), EUCO 163/14, CO EUR 11, CONCL 4.

EC 2014e, European Council 23/24 OCTOBER 2014 Conclusions, Brussels, 24 October 2014, EUCO 169/14, CO EUR 13, CONCL 5.

EC 2014f, European Council 18 DECEMBER 2014 Conclusions, Brussels 18 December, EUCO 237/14, CO EUR 16, CONCL 6.

EC 2015, European Council meeting (19 and 20 March 2015) - Conclusions, Brussels, 20 March 2015, EUCO 11/15, CO EUR 1, CONCL 1. 
EC 2016a, European Council meeting (28 June 2016) - Conclusions, Brussels, 28 June 2016, EUCO 26/16, CO EUR 5, CONCL 3.

EC 2016b, European Council meeting (20 and 21 October 2016) - Conclusions, Brussels, 21 October 2016, EUCO 31/16, CO EUR 8, CONCL 4.

EC 2016c, European Council meeting (15 December 2016) - Conclusions, Brussels, 15 December 2016, EUCO 34/16, CO EUR 10, CONCL 5.

Latosińska A. (2016), Ukraina w polityce zagranicznej Polski (2004-2014), in: Polityka zagraniczna Polski. 25 lat doświadczeń, eds. M. Pietrasiak, M. Stelmach, K. Żakowski, Łódź.

Milczarek D., Zajączkowski K. (2015), Potęga i niemoc. Unia Europejska jako aktor w stosunkach międzynarodowych (część 1), "Studia Europejskie", no. 1.

Nichol J. (2009), Russia-Georgia Conflict in August 2008: Context and Implications for the US Interests, Congressional Research Service, March 3.

Piskorska B. (2009), Wymiar wschodni Unii Europejskiej - komplementarny czy konkurencyjny dla pozostałych kierunków polityki zagranicznej Unii?, „Środkowoeuropejskie Studia Polityczne”, no. 1-2.

Przybylska-Maszner B., Rewizorski M. (2012), System instytucjonalny Unii Europejskiej po traktacie z Lizbony. Aspekty polityczne i prawne, Warszawa.

Rewizorski M. (2013), Zasady systemu instytucjonalnego Unii Europejskiej, “Studia Europejskie”, no. 1.

Rittelmeyer Y-S. (2014), The institutional consecration of the European Council: symbolism beyond formal texts, in: The European Council and European Governance. The commanding heights of the EU, eds. F. Foret, Y-S. Rittelmeyer, London-New York.

Tallberg J. (2008), Bargaining Power in the European Council, "Journal of Common Market Studies", vol. 46 , no. 3 .

Werts J. (2008), The European Council, London.

Wessels W. (2016), The European Council, London-New York.

\section{Rada Europejska i działania zewnętrzne Unii Europejskiej. Tworzenie relacji ze wschodnimi sąsiadami}

\section{Streszczenie}

Proces zmieniania porządku instytucjonalnego Unii Europejskiej wydaje się mieć charakter ciągły. Jednym z jego elementów jest pozycja Rady Europejskiej, szczególnie ciekawa w zakresie stymulowania działań zewnętrznych UE. Celem niniejszej analizy jest zbadanie zaangażowania Rady Europejskiej w inicjowanie relacji zewnętrznych, z sąsiedztwem wschodnim jako przykładem. Prezentowany artykuł bada spotkania Rady Europejskiej w okresie 2008-2016, dochodząc do wniosku, że kreatywnie odpowiadała ona w tym czasie na wyzwania zewnętrzne i kreowała impet polityczny dla działań innych instytucji. Wewnętrzna debata zainicjowana przez państwa członkowskie z Europy Środkowej i Wschodniej doprowadziła do sformułowania inicjatywy Partnerstwa Wschodniego, zatwierdzonej i przyjętej przez Radę Europejską, która nadała jej polityczny impet wewnątrz Unii Europejskiej. To spowodowało specyficzną reakcję wśród państw sąsiedzkich. Procesowi stowarzyszania niektórych partnerów ze wschodu kontynentu towarzyszyła konieczność podjęcia trudnej reakcji na odpowiedź ze strony Rosji, która między innymi uciekła się do działań wojskowych. Zaangażowanie Rady Europejskiej w działania zewnętrzne na wschodzie stało się procesem samopogłębiającym, jednakże ze zmieniającym się profilem i priorytetami.

Słowa kluczowe: Rada Europejska, działania zewnętrzne, Partnerstwo Wschodnie, Unia Europejska 